\title{
Approach of Cobb Douglas Function Into Scheme of Ijarah Muntahiya Bittamlik (IMBT)
}

\author{
Rini Cahyandari ${ }^{1, *}$, Asep Solih Awalluddin ${ }^{2}$, Acep Hidayat ${ }^{3}$ \\ 1,2,3 Department of Mathematics, UIN Sunan Gunung Djati Bandung \\ *Email: *rini_cahyandari@uinsgd.ac.id
}

\begin{abstract}
Ijarah Muntahiya Bittamlik (IMBT) is a scheme for the sale of goods or services that combines a sale and purchase contract and a lease agreement ending with the ownership of the goods or services that are the object of the contract in the hands of the tenant. In the IMBT scheme, the tenant makes payments for the compensation agreed in the contract to a sharia financing company (PPS) which is generally done every month and is called Ujroh. Thus, Ujroh is a compensation payment, which becomes monthly profit of the company. In this research, Ujroh calculation was conducted in 2019 for PT Adira Finance using approach of Cobb Douglas function, especially profit function. Financial data of PT Adira Finance since 2011 up to 2018 was taken secondary then analyzed using the maximum likelihood estimation method assisted with methods of Newton Raphson and Matlab software, so that obtained a model of profit function of Cobb Douglas will be used to calculate Ujroh for next year. It was obtained results that Ujroh scores for 2019 were not too far from Ujroh scores in previous years so it can be said that the Cobb Douglas functional approach in the IMBT scheme is quite good.
\end{abstract}

Keywords: Ijarah Muntahiya Bittamlik, Ujroh, Cobb Douglas Function, Maximum Likelihood Estimation Method.

\section{INTRODUCTION}

Ijarah Muntahiya Bittamlik (IMBT) is a scheme for the sale of goods or services that combines a sale and purchase contract and a lease agreement ending with the ownership of the goods or services that are the object of the contract in the hands of the tenant. Scheme of Ijarah Muntahiya Bittamlik (IMBT) illustrated by Figure 1,

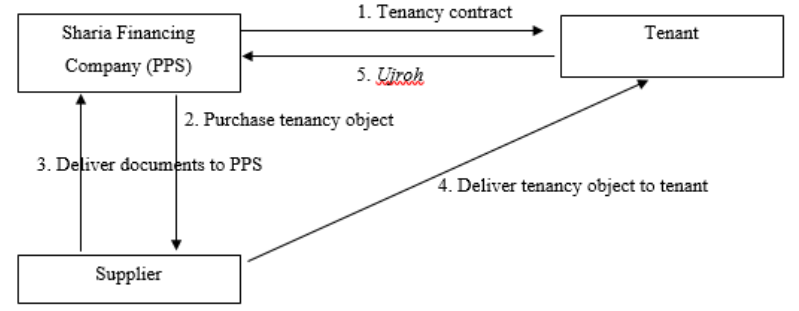

Figure 1. Scheme of Ijarah Muntahiya Bittamlik

The explanation of each number ini Figure 1 is as follows:

1. Sharia Financing Company (PPS) and the tenant do the contract of Ijarah Muntahiya Bittamlik (IMBT). In the contract, it is explained about the object of the tenancy, the period, and the benefits given by the tenant to the PPS.
2.PPS purchases tenancy objects from supplier. The tenancy object purchased by PPS is adjusted to the needs of the tenant.

3. After supplier provided the tenancy object, then supplier delivers the document of purchased object to PPS, PPS then pays supplier.

4. The supplier delivers the tenancy object to the tenant on orders from the PPS. The object delivered is not accompanied by documents, because the object documents are submitted to PPS.

5. After receiving the object of the tenancy, the tenant begins to pay the compensation agreed in the contract, which is generally done monthly. The reward received by PPS is called tenancy income or Ujroh. When the tenancy expires, the object of which is leased by the PPS is not necessarily to be returned back, but belongs to Tenant.

Tenancy income of Ujroh is determined by Sharia Financing Company by considering several factor adjusted with offered object to tenant. For example, in this research, Ujroh determination is conducted by using approach of Cobb Douglas function, especially profit function with influencing factors others are total of fixed input and total of irregular input. Method used to estimate parameter on Cobb Douglas function is 
likelihood maximum method assisted with methods of Newton Raphson and Matlab software, so as obtained equations of Cobb Douglas function that can be used to calculate Ujroh for the next year.

\section{COBB DOUGLAS FUNCTION}

\subsection{The Cobb Douglas Production Function}

The production function of Cobb Douglas written by the equation asfollows:

$y_{i}=f(X, Z)=A X_{\mathrm{i}}{ }^{\alpha} Z_{\mathrm{i}}^{\beta} e^{\varepsilon_{\mathrm{i}}}$

$\eta i=1,2,3, \ldots, n$

by assuming that the independent variable with their respective parameters is $X_{i}^{\square}=\left(x_{i 1}^{\Phi_{1}} \times x_{i 2}^{\Phi_{2}} \times x_{i a}^{\square_{3}} \ldots x_{i k}^{\square_{k}}\right)$ and $Z_{i}^{\beta}=\left(\mathbb{z}_{i 1}^{\beta_{1}} \times \mathbb{Z}_{i 2}^{\beta_{2}} \times \mathbb{Z}_{i a}^{\beta_{3}} \ldots \mathbb{z}_{i m}^{\beta_{1 m}}\right)$, thus

$y_{1}=A X_{1}^{\infty} Z_{1}^{\beta} e^{\epsilon_{1}}$

$y_{1}=A\left(x_{11}^{\alpha_{1}} x_{12}^{\sigma_{2}} x_{13}^{\sigma_{3}} \ldots x_{1 k}^{\alpha_{k}}\right)\left(z_{11}^{\beta_{1}} z_{12}^{\beta_{2}} z_{13}^{\beta_{3}} \ldots z_{1 m}^{\beta_{1 n}}\right) e^{\epsilon_{1}}$

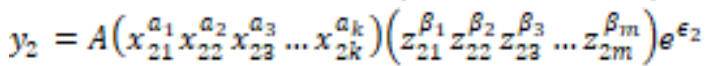

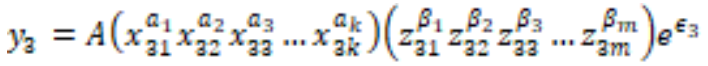

:

$y_{n}=A\left(x_{n 1}^{\alpha_{1}} x_{n 2}^{\alpha_{2}} x_{n 2}^{\alpha_{3}} \ldots x_{n k}^{\alpha_{k}}\right)\left(z_{n 1}^{\beta_{1}} z_{n 2}^{\beta_{2}} z_{n 2}^{\beta_{3}} \ldots z_{n m}^{\beta_{n n}}\right) e^{\epsilon_{n n}}$

equation (1) can be rewritten in general be:

$y_{i}=A \prod_{j=1}^{k} x_{i j}^{a_{j}} \prod_{t=1}^{m} z_{i t}^{\beta_{i}} e^{E_{i}}$

$\eta i=1,2,3, \ldots, n$

where

$y_{i} \quad$ : Total output per time period

$x_{i} \quad$ : Irregular input amount

$z_{\mathrm{i}} \quad$ : Fixed input amount

$A_{v} a, \beta \quad$ :Model parameters with $A \geq 0$ while $a_{b} b \in \forall Q$

$\varepsilon_{\mathrm{i}} \quad$ : Error per time period

\subsection{The Cobb Douglas Profit Function}

In general, profit or Ujroh is the difference between revenue gross with total expenses. In technical, profit is calculated from the results of subtraction of the total income of the total cost, with the equation as follows:

$\pi=T R-T C$

where

$\begin{array}{ll}\pi & \text { : Profit (Ujroh) } \\ T R & \text { : Total Revenue } \\ \text { TC } & \text { : Total Cost }\end{array}$

Equation (3) states that the maximum profit can be obtained if the company maximizes production output by assuming that all goods are sold out. Using production function concept and profit (Ujroh) $\pi$ of Cobb Douglas with assumptions:

$T R=k \cdot f(X, Z)$

$T C=W X=w_{1} \times x_{1}+w_{2} \times x_{2}+w_{3} \times x_{a}+\cdots+w_{k} \times x_{k}$

then the equation (3) can be rewritten into:

$\pi=k \cdot f(X, Z)-\sum_{j=1}^{k} w_{j}, x_{j}$ where

$w \quad$ : Costs of expenses

$k \quad$ : Sales price per unit

Furthermore, the UOP profit function or Unit Output Price profit function is obtained by dividing the two sides of the equation (4) by the selling price per unit $k$, obtained $\pi^{*}=\frac{\pi}{k}=\frac{k_{i} f\left(x_{,} z\right)}{k}-\frac{\sum_{j=1}^{k} W_{j} x_{j}}{k}$

$=f(X, Z)-\sum_{j=1}^{k} w_{j}^{*} \cdot x_{j}^{*}$

where $\pi^{*}=\frac{\pi}{k}$ and $\sum_{j=1}^{k} w_{j}^{*} \cdot x_{j}^{*}=\frac{\sum_{j=1}^{k} w_{j} x_{j}}{k}$

To gain the maximum profit, equation (5) is derived by assuming that $\frac{d \pi^{\infty}}{d x_{1}^{m}}=0$,

$$
\begin{aligned}
& \frac{d \pi^{*}}{d x_{j}^{*}}=0=\frac{d f\left(X_{0}, Z\right)}{d x_{j}^{*}}-\frac{d \sum_{j=1}^{k} w_{j}^{*} \cdot x_{j}^{*}}{d x_{j}^{*}} \\
& 0=\frac{d f(X, Z)}{d x_{j}^{*}}-\frac{d \sum_{j=1}^{k} w_{j}^{*} \cdot x_{j}^{*}}{d x_{j}^{*}} \\
& 0=\frac{d f\left(X_{v}, Z\right)}{d x_{j}^{*}}-\left(\frac{d w_{1}^{*} x_{1}^{*}}{d x_{1}^{*}}+\frac{d w_{2}^{*} x_{2}^{*}}{d x_{2}^{*}}+\frac{d w_{j}^{*} x_{1}^{*}}{d x_{a}^{*}}+\cdots+\frac{d w_{k}^{*} x_{k}^{*}}{d x_{k}^{*}}\right) \\
& 0=\frac{d f\left(X_{s}, Z\right)}{d x_{j}^{*}}-\left(w_{1}^{*}+w_{2}^{*}+w_{j}^{*}+\cdots+w_{k}^{*}\right) \\
& \frac{d f(X, Z)}{d x_{j}^{*}}=\sum_{i=1}^{k} w_{j}^{*} \\
& 0=\sum_{j=1}^{k} w_{j}^{*}
\end{aligned}
$$

thus concluded that the company will gain maximum profit when there is not expenses cost at all $\sum_{j=1}^{k} w_{j}^{*}=0$.. That is, assuming that $w_{1}^{*}=w_{2}^{*}=$ $w_{a}^{*}=\cdots=w_{k}^{*}=0$ so that equation (5) can be rewritten into

$$
\begin{aligned}
& \pi^{*}=f(X, Z)-\sum_{j=1}^{k} w_{j}^{*} \times x_{j}^{*} \\
& \pi^{*}=f(X, Z)-\left(w_{1}^{*} \cdot x_{1}^{*}+w_{2}^{*} \cdot x_{2}^{*}+w_{3}^{*} \cdot x_{3}^{*}+\cdots+w_{k}^{*} \cdot x_{k}^{*}\right) \\
& \pi^{*}=f(X, Z)-\left(0 . x_{1}^{*}+0, x_{2}^{*}+0 . x_{1}^{*}+\cdots+0 . x_{k}^{*}\right) \\
& \pi^{*}=f(X, Z)
\end{aligned}
$$

It shows that the maximum benefit will be equal to the total revenue. But in reality it rarely happens, because each irregular input is $(\mathrm{x})$ the function of production certainly has a cost that must be spent by the company. Because the function of profit following the functions of production, then the Cobb Douglas profit function is written as follows:

$\boldsymbol{\pi}_{\mathrm{i}}=f(X, Z)=A \prod_{j=1}^{k} x_{i j}^{\alpha_{j}} \prod_{t=1}^{m} z_{i t}^{\beta_{i}} e^{\epsilon_{i}}$

where

$\boldsymbol{\pi}_{\tilde{i}} \quad$ : Profits

$x_{i} \quad$ : Irregular input amount

$\nabla_{i} \quad$ : Fixed input amount

$A_{s}, \beta, \quad$ :Model parameters with $A \geq 0$ while $a_{s} b \in \forall Q$

$\varepsilon_{\mathrm{i}} \quad$ : Error per time period 


\section{CASE STUDY}

Secondary data from PT. Adira Finance in 2011-2018 were used to illustrate the calculation of Ujroh with objects such as four wheeled vehicles. The contract which is carried out is Ijarah Muntahiya Bittamlik (IMBT) between the company and the tenant.

Table 1. Financial Data of PT. Adira Finance

\begin{tabular}{|c|c|c|c|c|}
\hline Year & $\begin{array}{c}\text { Ujroh } \\
\text { (Million) }\end{array}$ & $\begin{array}{c}\text { Salary } \\
\text { Expenses }\end{array}$ & $\begin{array}{c}\text { Amount of } \\
\text { Cars }\end{array}$ & $\begin{array}{c}\text { Amount of } \\
\text { Investors }\end{array}$ \\
\hline 2011 & $5,701.16$ & $3,559.91$ & 270 & 3 \\
\hline 2012 & $7,962.86$ & $6,903.02$ & 441 & 3 \\
\hline 2013 & $22,190.74$ & $23,605.09$ & 1715 & 3 \\
\hline 2014 & $31,074.50$ & $44,155.00$ & 3398 & 3 \\
\hline 2015 & $28,997,871$ & $51,048.69$ & 3574 & 3 \\
\hline 2016 & $37,582.39$ & $37,923.66$ & 2387 & 3 \\
\hline 2017 & $22,068.40$ & $19,682.70$ & 1133 & 3 \\
\hline 2018 & $10,683.65$ & $8,734.84$ & 528 & 3 \\
\hline
\end{tabular}

Table 1 shows that companies that obtained Ujroh or profits every year, which was defined as the dependent variable with the burden of payroll and the number of cars as irregular independent variable and the number of investors are fixed independent variable.

By using the method of maximum likelihood assisted iteration of Newton Raphson and Matlab software, it is obtained estimates of parameters

$$
\left[\begin{array}{l}
A \\
\hat{a}_{1} \\
\hat{a}_{2} \\
\hat{\beta}_{1}
\end{array}\right]=\left[\begin{array}{c}
1.3652 \\
1.2988 \\
-0.5920 \\
0.8645
\end{array}\right]
$$

So that the function of profit Cobb Douglas ini equation (7) is rewritten into

$\hat{\boldsymbol{\pi}}=1.3652 . x_{1}^{1.2989} \cdot x_{2}^{-0.5920} \cdot z_{1}^{0.8645}$

Equation (8) can be used by companies to determine Ujroh in the following year. For example, in 2019 it was known that the salary burden was IDR 40,000 (Million), the number of cars was 2857 with the number of fixed investors, which were 3 , and then the amount of Ujroh for the company was

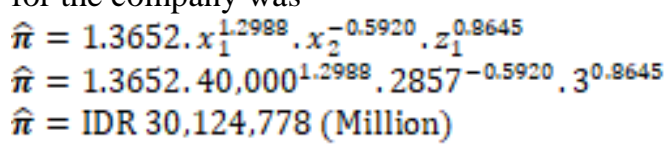

\section{CONCLUSION}

Based on case study and discussion above, obtained that Ujroh scores in 2019 were not too far from Ujroh scores in previous years with total of fixed input and irregular input have been determined before. So it can be said that the Cobb Douglas functional approach in the IMBT scheme is quite good.

\section{REFERENCES}

[1] Habieb M and Aziz E 2004 Matematika Ekonomi dan Bisnis (Bogor: Ghalia Indonesia)

[2] Sumarti N 2017 A Mathematics Model for Determinating the Value of Ijarah Contract, IOP Conf. Series: Materials Science and Engineering 288(1):012111

[3] Wulan E R 2016 Pengantar Metode Numerik (Bogor: Ghalia Indonesia)

[4] Walpole R E 1995 Pengantar Statistika Edisi ke-3 (Jakarta: PT. Gramedia Pustaka Utama) 